\title{
Yam: a neglected and underutilized crop in Brazil
}

\author{
Marcos VBM Siqueira \\ USP-ESALQ, Lab. Ecologia Evolutiva e Genética Aplicada, C. Postal 83, 13400-900 Piracicaba-SP; marcos.morruga@gmail.com
}

\begin{abstract}
In Brazil current studies and investments on yams are incipient. Similarly, the literature in recent decades lacks adequate information on this group of plants. The existing literature, on its turn, requires more than ever to be revised and organized. Yams have joined the so-called "neglected" group of crops for several reasons, but particularly because they are associated with poor and traditional communities. Many vegetables introduced in Brazil during the colonization period have adapted to different cropping systems, yams being an excellent example. This diversity resulted very widespread, yet poorly recognized in the country. In turn, the gardens using traditional farming systems continue to maintain and enhance yam local varieties. Studies from other countries, with an emphasis on characterization and genetic breeding, brought to light an urgent need for Brazil to invest in yams as a food rich in carbohydrates, even to the point of alterations in food public policy. Reversal of the yam's current stigma is both a challenge to the scientific community and to the population as a whole. This paper aims to raise pertinent questions about Dioscorea species, an important key group for many communities in tropical countries, yet still unrecognized as so in Brazil.
\end{abstract}

Keywords: Dioscorea spp., tubers, traditional agriculture, agrobiodiversity, molecular markers.

\section{RESUMO \\ Inhame: uma cultura negligenciada e subutilizada no Brasil}

No Brasil, estudos e investimentos ao inhame são incipientes. Similarmente, a literatura nas últimas décadas apresenta informações insuficientes para este grupo de plantas. A literatura existente, por sua vez, exige mais que nunca ser revisada e organizada. O inhame tem-se unido ao grupo de culturas ditas "negligenciadas" por diversas razões, mas particularmente devido ao fato de estar associado às comunidades pobres e tradicionais. Muitos vegetais introduzidos no Brasil durante o período da colonização têm-se adaptado a diferentes sistemas de cultivo, sendo o inhame um excelente exemplo. Esta diversidade é resultado de uma ampla dispersão, ainda pouco conhecida no país. Por sua vez, as roças usam o sistema de agricultura tradicional de forma a manter e aumentar as variedades locais de inhame. Estudos de outros países, com ênfase na caracterização e melhoramento genético, trouxeram à luz uma necessidade urgente de o Brasil investir em inhame como uma rica fonte de carboidratos, mesmo apesar das mudanças na política alimentar pública. Reverter o atual estigma do inhame é um duplo desafio para a comunidade científica e população como um todo. Este artigo objetiva-se a trazer questões pertinentes sobre as espécies do gênero Dioscorea, um importante grupo para muitas comunidades em países tropicais, contudo ainda pouco conhecido no Brasil.

Palavras-chave: Dioscorea spp., tubérculos, agricultura tradicional, agrobiodiversidade, marcadores moleculares.

\section{(Recebido para publicação em 1 de setembro de 2010 ; aceito em 2 de fevereiro de 2011) (Received on September1, 2010; accepted on February 2, 2011)}

\begin{abstract}
$\mathrm{C}$ ertain crops, such as yams, are associated with low-income communities, being a subsistence food source for many Brazilians. Despite the many contributions to human health from the active compounds found in several species, yams continue to be marginalized, hence have joined one of the many "orphan" crops. The yam is an underutilized crop, somewhat forgotten by society and not considered priority in political agendas (Siqueira \& Veasey, 2009). Yams are not even included in agricultural, government, or economic policies, which act as financial protectors and allow for trade of resources, especially exportable monocultures. Additionally, the species Colocasia esculenta is also called "yam"
\end{abstract}

in some regions of Brazil, making it difficult, for example, to distinguish the statistical production figures of these two different crops.

This neglected species is increasingly "forgotten" on the table of the rural population and still utterly unrecognized in large cities, hence the need for resurgence of its popularity. The spread of monocultures, the disappearance of traditional communities, changes in nutritional habits among younger generations, and lack of incentives for public and private institutions to focus on yam cultivation research, have made the following questions difficult to answer: (i) how this crop has diversified over the years in tropical countries, (ii) if there is wide biodiversity in these regions, as the question of genetic erosion risk rises, and (iii) how genetics can manifest itself in favor of yams.

Through advances in molecular biology, scientific data has shown the importance of cultivars beyond the perimeters of food. Other research, with reinforcement from new fields, such as ethnobotany, involves local communities that have genetic resources of inestimable value as local varieties (Peroni \& Hanazaki, 2002; Bressan et al., 2005; Zannou et al., 2006). However, how long will this gene pool exist in backyards and gardens throughout the tropics? The stimulus of applied studies (such as in vitro cultivation and genetic breeding), the strengthening of the entire supply chain 
(surely that would help marketing in an increasingly competitive market), and an effective conservation policy (a set of measures that focus on the small and medium farmer's role to maintain local varieties), are the main premises that can bring value back to yams. This resolution and other parallel issues would certainly put yams back in the spotlight, both domestically and internationally.

Thus, the goal of the present study was to review concepts regarding Dioscorea spp., focusing on how scientific research has been debated, with particular emphasis on issues related to in situ and ex situ conservation.

The yam today - Yam is currently the fourth most important tuber-root crop in the world, after potato (Solanum tuberosum L.), cassava (Manihot esculenta Crantz), and sweet potato (Ipomoea batatas L.). In 2008, the estimated world production of yams was 51.7 million tons, with Africa leading the production. The Brazilian production, in 2008, was 250,000 tons within a cultivated area of 27,000 ha (FAOSTAT, 2010). Thriving well in tropical and subtropical environmental conditions, varied yam species are satisfactorily developed in the Brazilian ecosystems, especially in the Northeast region of the country, where agriculture presents great economic potential (Santos, 1996). The highest production of yams in Brazil occurs mainly in the States of Paraíba, Pernambuco, Alagoas, Bahia, and Piauí, followed by others at a lesser scale (Mesquita, 2002).

The Dioscorea species has long been cultivated for their medicinal properties (sapogenin steroids, used in production of cortisone and synthetic hormones) in the following order of importance: D. bulbifera, D. cayenensis, D. dumentorum, D. alata, D. trifida, D. laxiflora, and D. microbotrya (Karnick, 1969; Pedralli, 2002). Wu et al. (2005) analyzed the consumption of $D$. alata by post-menopausal women and concluded that although the mechanisms are not yet fully understood, its consumption reduces the risk of breast cancer and cardiovascular disease. Among many of the yam medicinal properties, the prevention of diseases like malaria, yellow fever, and dengue is mentioned. Bhandari \& Kawabata (2004) have presented interesting information about the nutritional composition of several wild species and their possible application in modern medicine. Traditional medicine uses yams to cleanse skin impurities, for example, rashes. Nutritionists stress the importance of yams in treating anemic patients given their wealth of nutrients, vitamins, and minerals (Okwu \& Ndu, 2006). In Africa, it was found that the tuber is responsible for increased fertility in women who habitually consume it (Balbach \& Boarim, 1993).

Yam species, considered somewhat irrelevant on a commercial scale, began to receive recognition for their importance, as exemplified in $D$. bulbifera, from which diosgenin can be extracted (Narula et al., 2007) or even in its use as an anti-tumor agent (Gao et al., 2007). Among many other species of the same genus, is D. balkan, endemic to the Balkans and currently protected, however, sustainably extracted to obtain high concentrations of diosgenin (Fodulovicé et al., 1998). This example serves to illustrate the rich and untapped genetic resources found within the genus Dioscorea.

Even with all the economic and cultural significance that this crop entails for tropical countries, few studies using biochemical approaches or molecular markers have been conducted to understand the relationships and extent of genetic similarity between cultivated and wild yams (Tamiru et al., 2008). Consequently, farmers in some countries have reported the disappearance of many cultivars due specially to pests and diseases, which has led to significant genetic erosion (Mignouna \& Dansi, 2003).

Despite the minor effects of pests on yam cultivars in comparison to other crops, phytosanitary problems represent the main difficulties for producers. The virus [Yam mosaic virus (YMV)], anthracnose (caused by the fungus Glomerella cingulata), nematodes (Meloidogyne spp., Pratylenchus spp., and Scutellonema bradys), and tuber rot (Penicillium sclerotigenum and Rhizopus oryzae) are the main diseases and account for the highest field and storage losses in susceptible cultivars (Abang et al., 2003; Amusa et al., 2003). Anthracnose stands out as the principal phytosanitary problem in several areas of yam cultivation and production. Nematodes, which interact with fungi and bacteria, attack the tubers in the field and continue to cause damage in post harvest. The dry rot disease is also a limiting factor in yam cultivation and negatively influences the market value of the product, especially when found in conjunction with the nematode Scutellonema bradys, which acts as its etiologic agent. This disease is a serious problem because it still lacks effective countermeasures, hence remains lethal. Yam meloidogynoses are diseases caused by nematodes of the genus Meloidogyne, which show high incidence and severity in production, causing heavy losses in yam production and marketing (Abang et al., 2002; Mignouna et al., 2003b).

Micropropagation and organogenesis are two of many biotechnological techniques that could be adopted to obtain healthy seedlings, increasing the potential of cultivation (Alizadeh et al., 1998; Chen et al., 2003; Royero et al., 2007), especially in commercially valuable species, such as D. alata (Balogun et al., 2006).

Although of great importance, especially to subsistence communities, for its high nutritional quality and medicinal properties, there are unfortunately few institutions involved in research related to yam in Brazil. For this reason, as previously mentioned, further study is necessary to improve the knowledge on this species.

Origin, dispersal of species, and genetic contribution - With approximately 600 yam species, only few are known for their use in human consumption (D. alata, D.cayenensis, D. mummularia, D. opposita, D. rotundata, D. transverse, D. esculenta, D. bulbifera, D.trifida, and D. pentaphylla). The genus is quite dispersed and can be found throughout tropical, sub-tropical, and temperate regions (Lebot, 2009). Different yam cultivation practices, similar to historical and socio-cultural profiles, define an important force in the creation and maintenance of genetic 
diversity between each group in several areas of Africa (Baco et al., 2007). It is believed that a similar chain of events has also occurred in Brazil.

According to Lebot (2009), the genus dispersed worldwide at the end of the Cretaceous period, evolved in different directions throughout the New and Old World, and resulted in distinct species. The main dispersal regions for many of these species included the Americas, Africa, Madagascar, South and Southeast Asia, Melanesia, and Australia. According to Coursey (1967), separation of the Asian and African species occurred later, during the Miocene period. Furthermore, according to Coursey (1967), the species, D. alata and D. esculenta, originated from Burma and Assam, localities of Southeast Asia. Degras (1993) noted that D. cayenensis is of African origin, given that wild species can be found on the continent. The origins of other yam cultivated species are African and Asian, except for $D$. trifida, whose origin is South American (Lebot, 2009). In these regions, the yam has been cultivated by humans since the beginning of civilization, where its importance to the African peoples' diet has always been valued. Although cultivated since antiquity by native Indian communities, the yam cultivars only entered Western civilization when the black slave trade intensified. It is most likely that yams were introduced to Europe by merchants, especially by black slave traders. In Brazil, a similar history ensued, however native Indians blended with introduced slaves in various states of the country during colonization (Madeira et al., 2008). According to Silva (1971), in the early twentieth century, the Rondon Commission found isolated tribes in the northwest of Mato Grosso, Brazil, cultivating the species $D$. trifida where they named it "cará mimoso".

Dioscorea spp. is commonly known as "cará" or yam in Brazil. Due to the ethnic richness in tropical countries, there is a wide diversity of vernacular names assigned to species (Pedralli et al., 2002; Bressan et al., 2005; Tamiru et al., 2008). The name "igname" or "yam" seems to have an African origin.
Thus, it appears that the word "inhame" is a translation of the terms, "yam" or "igname", used originally in English and French colonies in Africa. As for the word "cará", based on historical Brazilian documents, it seems to be of native Indian origin (Cascudo, 1983). In Portuguese, especially in the Northeast region of Brazil, there is a tendency to apply the name "yam" to large tubers of D. cayenensis and the name "cará" to the smaller tubers of $D$. alata (Peixoto Neto et al., 2000).

One aspect that makes yams well known in Brazil is the strong African influence on the Northeastern cultures. Despite being increasingly abandoned, communities still maintain their dietary value and use yam in cultural dishes. Recently, it is notable that there is a presence of yams in some supermarket chains, small retail markets, and farmers markets, which has encouraged some agriculturists to increase cultivation of this species. At first one might think that the explanation for this may be related to the diet of the Northeastern population. However, in recent years, the media has explored several issues related to health and nutrition, which may be stimulating yam consumption in the pursuit of alternative starch sources (Hsu et al., 2004; Ukpabi, 2010).

In Brazil, no data exists yet about the diversity of the yam based on molecular markers. The most relevant studies came from Africa, the main origin and dispersal centers of some yam species. Studies of genetic diversity in 269 cultivars of $D$. alata from the South Pacific, Asia, Africa, the Caribbean, and South America (Lebot et al., 1998), concluded that many yams exhibited diverse variations, most likely due to human selection. In Brazil, isozymes were used to study the genetic diversity among local varieties of $D$. alata, $D$. bulbifera, D. cayenensis, and D. trifida in the Ribeira Valley, on the coast of São Paulo State. The results of this study showed a high genetic diversity maintained by farmers in this region, and that this variability was not structured in space (Bressan, 2005). RAPD markers were used to evaluate intraspecific variation in accessions of $D$. alata from Jamaica (Asemota et al., 1996), to compare Dioscorea species from Africa, Asia and Polynesia (Ramser et al., 1996), and to characterize accessions in the D. cayenensis-rotundata complex (Hamon \& Toure, 1990; Dansi et al., 2000b). AFLP markers were used to assess the genetic diversity of $D$. alata in relation with nine other species of edible yams (Malapa et al., 2005) and to study domestication of genus Dioscorea (Scarcelli et al., 2006). Egesi et al. (2006), using these markers, were able to show, from 53 accessions of $D$. alata in west and central Africa, that each group formed was a mixture of different geographical origins, indicating that geography has played a central role in species differentiation.

Isozymes, RAPD and microsatellites have contributed to the determination of the $D$. cayenensis-rotundata complex, which some have considered not to be two separate species, but as a species complex (Dansi et al. 2000a,b; Chaïr et al., 2005; Obidiegwu et al., 2009a). Fundamentally, microsatellite markers have been used to study the segregation patterns and characterization of several Dioscorea species (Mignouna et al., 2003a; Mignouna et al., 2003b; Scarcelli et al., 2005; Hochu et al., 2006; Obidiegwu et al., 2009b).

Part of the complexity in genetic studies of the yam is due to its ploidy. The basic chromosome number of Dioscorea species is considered to be $\mathrm{x}$ $=10$ and $\mathrm{x}=9$, with a high frequency of polyploid species (Abraham, 1998). Tetraploid species are most frequent, followed by types $2 \mathrm{x}, 6 \mathrm{x}$, and $8 \mathrm{x}$ in similar proportions. The basic number of chromosomes $(\mathrm{x}=10)$ is found in $52 \%$ of African species and $13 \%$ of American species. The remaining African and American species have the basic number $\mathrm{x}=9$. However, recent studies show two new basic chromosome numbers, $\mathrm{x}=6$ (Segarra-Moragues et al., 2004) and $\mathrm{x}=20$ for $D$. rotundata (Scarcelli et al., 2005) and D. trifida (Bousalem et al., 2006). If these basic numbers are confirmed in a large proportion of species, the basic chromosome number of the genera may be reconsidered, leading to a decrease in the ploidy level in some species (Bousalem et al., 2006; Arnau et al., 2009). 
Accurate information on genetic diversity is critical to the success of breeding programs, since genetic divergence produces high heterotic effects and, therefore, desirable segregants for the purposes of each program. In this sense, molecular markers have contributed to the advancement of measures not only for protection, but improvement, which many producers have already benefited from. The literature shows actions and consequences of the replacement of local varieties by other more productive by gene banks and research centers, bringing losses to yam ethnovarieties (Tamiru et al., 2008). As a consequence of stress agents, the issue of genetic erosion of local varieties generates a heated debate, demanding effective measures by government and more interaction among the few gene banks of the genera.

Final Considerations - Based on what has been reported, it becomes clear that studies involving yam cultivation, whether for conservation or breeding, especially in Brazil, are still incomplete. Urgent government intervention with a number of measures to aid researchers, extension workers, and farmers is necessary for several reasons, and the risk of genetic erosion is one of the main issues. In this context, it is hoped that the Yam and Taro Symposium will return to Brazil, where the second, and last, took place in 2002. This would be an excellent opportunity to share problematic yam insights; helping traditional, local, and large-scale farmers.

The unknown diversity of Dioscorea in Brazil, with a wide range of local varieties and agroecosystems, is an information blank for breeding and conservation programs. Thus, coupled with an urgency to reinforce to the new generations how important is the yam as a healthy food source, multidisciplinary analysis is crucial for future progresses.

\section{ACKNOWLEDGEMENTS}

The author would like to thank Elizabeth Ann Veasey, Paulo César Tavares de Melo and Josh Halsey for contributions to the manuscript. The author is also grateful to The São Paulo Research Foundation (process 2007/07222-8).

\section{REFERENCES}

ABANG MM; WINTER S; GREEN KR; HOFFMANN P; MIGNOUNA HD; WOLF GA. 2002. Molecular identification of Colletotrichum gloeosporioides causing anthracnose of yam in Nigeria. Plant Pathology 51: 63-71.

ABANG MM; WINTER S; MIGNOUNA HD; GREEN KR; ASIEDU R. 2003. Molecular taxonomic, epidemiological and population genetic approaches to understanding yam anthracnose disease. African Journal of Biotechnology 2: 486-496.

ABRAHAM K. 1998. Occurrence of hexaploid males in Dioscorea alata L. Euphytica 99: $5-7$.

ALIZADEH S; MANTELL SH; VIANA AM 1998. In vitro shoot culture and microtuber induction in the steroid yam Dioscorea composita Hemsl. Plant Cell Tissue and Organ Culture 26:147-152.

AMUSA NA; ADEGBITE AA; MUHAMMED S; BAIYEWU RA. 2003. Yam diseases and its management in Nigeria. African Journal of Biotechnology 2: 497-502.

ARNAU G; NEMORIN A; MALEDON E; ABRAHAM K. 2009. Revision of ploidy status of Dioscorea alata L. (Dioscoreaceae) by cytogenetic and microsatellite segregation analysis. Theoretical and Applied Genetics 118:1239-1249.

ASEMOTA HN; RAMSER J; LOPÉZ-PERALTA C; WEISING K; KAHL G. 1996. Genetic variation and cultivar identification of Jamaican yam germplasm by random amplified polymorphic DNA analysis. Euphytica 92: 341-351.

BACO MN; BIAOU G; JEAN-PAUL L. 2007. Complementarity between Geographical and Social Patterns in the Preservation of Yam (Dioscorea sp.) Diversity in Northern Benin. Economic Botany 61: 385-393.

BALBACH A; BOARIM DFS. 1993. As hortaliças na medicina natural. São Paulo: Missionária. 436p.

BALOGUN MO; FAWOLE I; NG SYC; NG NQ; SHIWACHI H; KIKUNO H. 2006. Interaction among cultural factors in microtuberization of white yam (Dioscorea rotundata). Tropical Science 46:55-59.

BHANDARI MR; KAWABATA J. 2004. Organic acid, phenolic content and antioxidant activity of wild yam (Dioscorea spp.) tubers of Nepal. Food Chemistry 88:163-168.

BOUSALEM M; ARNAU G; HOCHU I; ARNOLIN R; VIADER V; SANTONI S; DAVID J. 2006. Microsatellite segregation analysis and cytogenetic evidence for tetrasomic inheritance in the American yam Dioscorea trifida and a new basic chromosome number in the Dioscorea. Theoretical and Applied Genetics 113: 439-451.

BRESSAN EA; VEASEY EA; PERONI N;
FELIPIM AP; SANTOS KMP. 2005. Collecting yam (Dioscorea spp.) and sweet potato (Ipomoea batatas) germplasm in traditional agriculture small-holdings in the Vale do Ribeira, São Paulo, Brazil. Plant Genetic Resources Newsletter 144: 8-13.

BRESSAN EA. 2005. Diversidade isoenzimática e morfológica de inhame (Dioscorea spp.) coletados em roças de agricultura tradicional do Vale do Ribeira-SP. Piracicaba: USPESALQ. 172p. (Master thesis).

CASCUDO LC. 1983. História da alimentação no Brasil. Belo Horizonte: Itatiaia; São Paulo: EDUSP; v.1-2. 926p.

CHAIIR H; PERRIER X; AGBANGLA C; MARCHAND JL; DAINOU O; NOYER JL. 2005. Use of cpSSRs for the characterisation of yam phylogeny in Benin. Genome 48: 674-684.

CHEN YQ; FAN JY; YI F; LUO ZX; FU YS. 2003. Rapid clonal propagation of Dioscorea zingiberensis. Plant Cell Tissue Organ Culture 73: 75-80.

COURSEY DG. 1967. Yams. An account oh the nature, origins, cultivation and utilization of the useful members of discoreaceae. Tropical Agricultural Series. Longmans, Green and Co. Ltd. Londres, UK., 230p.

DANSIA; MIGNOUNAHD;ZOUNDJIHEKPON J; SANGARE A; ASIEDU R; AHOUSSOU N. 2000a. Using isozyme polymorphism to assess genetic variation within cultivated yams (Dioscorea cayenensis/Dioscorea rotundata complex) of the Republic of Benin. Genetic Resources and Crop Evolution 47: 371-383.

DANSIA; MIGNOUNAHD;ZOUNDJIHEKPON J; SANGARE A; AHOUSSOU N; ASIEDU R. 2000b. Identification of some Benin Republic's Guinea yam (Dioscorea cayenensis/rotundata complex) cultivars using Randomly Amplified Polymorphic DNA. Genetic Resources and Crop Evolution 47: 619-625.

DEGRAS L. 1993. The Yam: a Tropical Root Crop. The Macmillan Press Ltd, London, UK, 408p.

EGESI CN; ASIEDU R; UDE G; OGUNYEMI S; EGUNJOBI JK. 2006. AFLP marker diversity in water yam (Dioscorea alata L.). Plant Genetic Resources 4:181-187.

FAOSTAT - Food and Agriculture Organization of the United Nations. 2010. Avalailable at http://www.fao.org

FODULOVICÉ KS; GRUBISIÉ D; CÚLAFIÉ L; MENKOVIÉ N; RISTICÉ M. 1998. Diosgenin and phytosterols content in five callus lines of Dioscorea balcanica. Plant Science 135: 63-67.

GAO H; HOU B; KUROYANAGI M; WU L. 2007. Constituents from anti-tumor-promoting active part of Dioscorea bulbifera L. Asian Journal of Traditional Medicines 2: 104109.

HAMON JR; TOURE B. 1990. Characterization of traditional yam varieties belonging to the Dioscorea cayensis-rotundata complex by their isozymic patterns. Euphytica 46: 101-107.

HOCHU I; SANTONI S; BOUSALEM M. 2006. Isolation, characterization and cross-species amplification of microsatellite DNA loci in 
the tropical American yam Dioscorea trifida. Molecular Ecology Notes 6: 137-140.

HSU CL; HURANG SL; CHEN W; WENG YM; TSENG CY. 2004. Qualities and antioxidant properties of bread as affected by the incorporation of yam flour in the formulation. International Journal of Food Science and Technology 39: 231-238.

LEBOT V. 2009. Tropical root and tuber crops Cassava, sweet potato, yams and aroids. Publ. CABI. 413p.

LEBOT V; TRILLES B; NOYER JL; MODESTO J. 1998. Genetic relationships between Dioscorea alata L. cultivars. Genetic Resources and Crop Evolution 45: 499-509.

KARNICK CR. 1969. Dioscorea (YAMS) - The Food of the Slaves, with Potentials for Newer Drugs: A review, Pharmaceutical Biology 9: 1372-1391.

MADEIRA NR; REIFSCHNEIDER FJB; GIORDANO LB. 2008. Contribuição portuguesa à produção e ao consumo de hortaliças no Brasil: uma revisão histórica. Horticultura Brasileira 26: 428-432.

MALAPA R; ARNAU G; NOYER JL; LEBOT V. 2005. Genetic diversity of the greater yam (Dioscorea alata L.) and relatedness to D. nummularia Lam. and D. transversa Br. as revealed with AFLP markers. Genetic Resources and Crop Evolution 52: 919-929.

MESQUITAAS. 2002. Inhame e taro: cenários dos mercados internacional, brasileiro e baiano. Bahia Agrícola 5: 54-64.

MIGNOUNA HD; ABANG MM; FAGBEMI SA. 2003a. A comparative assessment of molecular marker assays (AFLP, RAPD and SSR) for white yam (Dioscorea rotundata) germplasm characterization. Annals of Applied Biology 142: 269-276.

MIGNOUNA HD; ABANG MM; ASIEDU R. 2003b. Harnessing modern biotechnology for tropical tuber crop improvement: Yam (Dioscorea spp.) molecular breeding. African Journal of Biotechnology 2: 478-485

MIGNOUNA HD; DANSI A. 2003. Yam (Dioscorea ssp.) domestication by the Nago and Fon ethnic groups in Benin. Genetic Resources and Crop Evolution 50: 519-528.
NARULA A; KUMAR S; SRIVASTAVA PS. 2007. Genetic fidelity of in vitro regenerants, encapsulation of shoot tips and high diosgenin content in Dioscorea bulbifera L., a potential alternative source of diosgenin. Biotechnology Letter 29: 623-629

OBIDIEGWU JE; KOLESNIKOVA-ALLEN M; ENE-OBONG EE; MUONEKE CO; ASIEDU R. 2009a. SSR markers reveal diversity in Guinea yam (Dioscorea cayenensis/D. rotundata) core set. African Journal of Biotechnology 8: 2730-2739.

OBIDIEGWU JE; ASIEDU R; ENE-OBONG EE; MUONEKE CO; KOLESNIKOVA-ALLEN M. 2009b. Genetic characterization of some water yam (Dioscorea alata L.) in West Africa with simple sequence repeats. Journal of Food, Agriculture \& Environment 7: 3-4.

OKWU DE; NDU CU. 2006. Evaluation of the phytonutrients, mineral and vitamin contents of some varieties of yam (Dioscorea sp.). International Journal of Molecular Medicine and Advance Science 2: 199-203.

PEDRALLI G; CARMO CAS; CEREDA M; PUIATTI M. 2002. Uso de nomes populares para as espécies de Araceae e Dioscoreaceae no Brasil. Horticultura Brasileira 20: 530532.

PEIXOTO NETO PAS; LOPES FILHO J; CAETANO LC; ALENCAR LMC; LEMOS EEP. 2000. Inhame: O Nordeste Fértil. Maceió: EDUFAL, 88 p.

PERONI N; HANAZAKI N. 2002. Current and lost diversity of cultivated varieties, especially cassava, under swidden cultivation systems in the Brazilian Atlantic Forest. Agriculture, Ecosystems and Environment 92:171-183.

RAMSER J; LÓPEZ-PERALTA C; WETZEL R; WEISING K; KAHL G. 1996. Genomic variation and relationships in aerial yam (Dioscorea bulbifera L.) detected by random amplified polymorphic DNA. Genome 39: 17-25.

ROYERO M; VARGAS TE; OROPEZA M. 2007. Micropropagación y organogénesis de Dioscorea alata (Name). Interciencia 32: 247-252.

SANTOS ES. 1996. Aspectos básicos da cultura do inhame (Dioscorea spp.). João Pessoa-PB: EMEPA-PB, SEBRAE, 158 p.

SCARCELLI N; DAÏNOU O; AGBANGLA C; TOSTAIN S; PHAM JL. 2005. Segregation patterns of isozyme loci and microsatellite markers show the diploidy of African yam Dioscorea rotundata $(2 \mathrm{n}=40)$. Theoretical and Applied Genetics 111: 226-232.

SCARCELLI N; TOSTAIN S; MARIAC C; AGBANGLA C; DA O; BERTHAUD J; PHAM JL. 2006. Genetic nature of yams (Dioscorea sp.) domesticated by farmers in Benin (West Africa). Genetic Resources and Crop Evolution 53:121-130.

SEGARRA-MORAGUES JG; PALOP-ESTEBAN M; GONZÁLEZ-CANDELAS F; CATALÁN P. 2004. Characterization of seven (CTT)n microsatellite loci in the Pyrenean endemic Borderea pyrenaica (Dioscoreaceae). Remarks on ploidy level and hybrid origin assessed through allozymes and microsatellite analyses. Journal of Heredity 95: 177-183.

SILVA AA. 1971. Cultura do cará da costa. Fortaleza: Banco do Nordeste do Brasil. 65p.

SIQUEIRA MVBM; VEASEY EA. 2009. Raíces y tubérculos tropicales olvidados o subutilizados en Brasil. Revista Colombiana de Ciencias Hortícolas 3: 110-125.

TAMIRU M; BECKER HC; MAASS BL. 2008. Diversity, distribution and management of yam landraces (Dioscorea spp.) in Southern Ethiopia. Genetic Resources and Crop Evolution 55: 115-131.

UKPABI UJ. 2010. Farmstead bread making potential of lesser yam (Dioscorea esculenta) flour in Nigeria. Australian Journal of Crop Science 4:68-73.

WU WH; LIU LY; CHUNG CJ; JOU HJ; WANG TA. 2005. Estrogenic effect of yam ingestion in healthy postmenopausal women. Journal of the American College of Nutrition 24: 235-243.

ZANNOU A; RICHARDS P; STRUIK PC. 2006. Knowledge on yam variety development: insights from farmers' and researchers' practices. Knowledge Management for Development Journal 2: 30-39. 


\title{
Pesquisa / Research
}

NASCIMENTO WM; LIMA GP; CARMONA R. 2011. Influência da quantidade de pólen na produção e qualidade de sementes híbridas de abóbora. Horticultura Brasileira 29: 21-25.

\section{Influência da quantidade de pólen na produção e qualidade de sementes híbridas de abóbora}

\author{
Warley Marcos Nascimento ${ }^{1}$; Graziele P Lima ${ }^{2}$; Ricardo Carmona ${ }^{3}$ \\ ${ }^{1}$ Embrapa Hortaliças, C. Postal 218, 70351-970 Brasília-DF; ${ }^{2}$ Coordenação de Sementes e Mudas, Ministério da Agricultura, Pecuária e \\ Abastecimento, Brasília-DF; ${ }^{3} \mathrm{UnB}$, C. Postal 4508, 70910-970 Brasília-DF; wmn@cnph.embrapa.br; grazi.lima@bol.com.br; rcar- \\ mona@unb.br
}

\section{RESUMO}

A baixa produção de sementes híbridas de abóbora obtida em nossas condições deve-se provavelmente aos métodos de produção pouco eficientes. A quantidade de pólen transferido naturalmente ou artificialmente entre os parentais pode afetar não só a produção como também a qualidade das sementes híbridas. Neste estudo, utilizou-se a polinização manual, a qual constou de cinco tratamentos relacionados com a quantidade de pólen do progenitor masculino para polinizar uma única flor feminina: um quarto da quantidade de pólen de uma flor; metade da quantidade de pólen de uma flor; a quantidade de pólen de uma flor; a quantidade de pólen de duas flores, e a quantidade de pólen de quatro flores masculinas. O delineamento experimental adotado foi em blocos ao acaso, com três repetições e dezoito plantas por parcela. O aumento da quantidade de pólen aplicada aumentou a produção de sementes por fruto e consequentemente a produção de sementes por área. A qualidade fisiológica das sementes praticamente não foi afetada entre os tratamentos, embora foi observada uma menor germinação das sementes obtidas em frutos provenientes de flores polinizadas com $1 / 4$ de pólen.

Palavras-chave: C. maxima, C. moschata, flores, polinização.

\begin{abstract}
Influence of pollen amount on production and quality of squash hybrid seeds
\end{abstract}

The low production of squash hybrid seeds obtained in our conditions is probably due to the inefficient production methods. The amount of pollen transferred naturally or artificially between the two parents may affect not only the hybrid seed production but also the seed quality of squash. In this study, flowers were manually pollinated using five amounts of pollen to pollinate one female flower: $1 / 4$ of pollen from one flower; half of the amount of pollen from one flower; pollen of one flower; pollen of two flowers and pollen of four flowers. The randomized complete block design was adopted, with three replications and eighteen plants per plot. The increasing pollen amount affected significantly seed yield per fruit and seed yield per area, but did not influence significantly seed quality. A lower germination was observed in fruits originated from flowers pollinated with $1 / 4$ of pollen of one flower.

Keywords: C. maxima, C. moschata, flowers, pollination.

(Recebido para publicação em 3 de novembro de 2008; aceito em 12 de janeiro de 2011) (Received on November 3, 2008; accepted on January 12, 2011)

\begin{abstract}
A s abóboras, do ponto de vista sócio econômico, são importantes por fazerem parte da alimentação básica das populações de várias regiões do nosso país, tendo alcançado em 2002 o volume comercializado de $30.300 \mathrm{t}$ (CEAGESP-SP) (Agrianual, 2004). Embora diversos híbridos nacionais de abóbora tipo tetsukabuto já tenham sido desenvolvidos, a produção de sementes em nossas condições não tem sido eficiente, impossibilitando o atendimento de toda a demanda interna. Para tanto, é importada a quase totalidade das sementes utilizadas para a produção de abóbora do tipo tetsukabuto, em uma estimativa de $10 \mathrm{t} / \mathrm{ano}$, com um custo de US\$ 1 milhão (Embrapa, 2003). Este valor pode chegar a US\$2,4 milhões, a nível de produtor. Produtividades
\end{abstract}

variando de 50 a $100 \mathrm{~kg} / \mathrm{ha}$ de sementes híbridas têm sido obtidas em nosso país. Diferentes causas para esta baixa produção de sementes em nossas condições podem estar ocorrendo, incluindo uma deficiência da polinização.

Para a obtenção de sementes híbridas de abóbora do tipo tetsukabuto é realizado o cruzamento de uma linhagem de moranga (Cucurbita maxima), como parental feminino, com uma linhagem de abóbora (Cucurbita moschata), sendo o parental masculino. Quando a produção de sementes híbridas é realizada em cultivos protegidos, os grãos de pólen de flores de C. moschata são transferidos manualmente para as flores femininas de C. maxima. O ovário das flores femininas de abóbora possui muitos óvulos, podendo formar várias sementes. Como cada grão de pólen tem a capacidade de fecundar apenas um óvulo, e a semente é originada de um óvulo fecundado, uma quantidade suficiente de grãos de pólen se torna necessária, para que nenhum óvulo deixe de ser fecundado. Segundo Freitas (1997), quanto mais eficiente for o processo de polinização, ou seja, quanto maior for o número de grãos de pólen viáveis e compatíveis no estigma, maior será a competição entre eles para fecundar os óvulos e maior será a percentagem de sementes formadas.

No caso da produção atual de sementes de Cucurbita, é importante salientar que o uso de polinização manual, com uma ou duas anteras por flor feminina tem sido utilizado e sementes mais vigorosas são obtidas quando utilizada a quantidade de pólen de uma flor em 
contraponto a meia flor (Lima et al., 2000). Um estudo mais detalhado de práticas de polinização se faz necessário para um possível aumento da quantidade de sementes híbridas de abóbora produzidas e, consequentemente, uma oferta suficiente de sementes com preços mais acessíveis. Este trabalho teve como objetivo determinar a influência da quantidade de pólen na produção e qualidade de sementes híbridas de abóbora.

\section{MATERIAL E MÉTODOS}

Este estudo foi conduzido na Embrapa Hortaliças, de novembro de 2002 a junho de 2003. O delineamento experimental foi em blocos ao acaso, utilizando cinco tratamentos, referentes à quantidade de pólen para polinizar cada flor: $11 \mathrm{mg}$ (1/4 da quantidade de pólen de uma flor), $23 \mathrm{mg}$ (1/2 da quantidade de pólen de uma flor), 47 mg (a quantidade de pólen de uma flor), $94 \mathrm{mg}$ (a quantidade de pólen de duas flores) e $188 \mathrm{mg}$ (a quantidade de pólen de quatro flores). Foram utilizadas três repetições e dezoito plantas por parcela. Linhagens femininas e masculinas de abóbora do híbrido 'Jabras' produzidas na Embrapa Hortaliças foram utilizadas neste estudo. As sementes de abóbora do progenitor masculino (Cucurbita moschata) foram semeadas em bandejas de poliestireno expandido (isopor) de 72 células, utilizando duas sementes por célula, em 18 de novembro de 2002. A semeadura do progenitor feminino (Cucurbita maxima) foi realizada diretamente no solo da casa de vegetação. Foram semeadas duas sementes por cova, em 04 de dezembro. Nesta mesma data também foi realizado o transplantio do progenitor masculino para a mesma casa de vegetação, na proporção de uma planta do progenitor masculino para quatro plantas do progenitor feminino. Essa diferença de 16 dias na semeadura teve como objetivo sincronizar o período de florescimento desses progenitores. As plantas foram desbastadas posteriormente, permanecendo apenas uma planta por cova. O espaçamento utilizado, para as duas espécies, foi de $1,0 \mathrm{~m}$ entre linha e $0,5 \mathrm{~m}$ entre plantas. A irrigação foi realizada sempre pela manhã, utilizando o sistema de gote- jamento, e o controle fitossanitário foi realizado sempre que necessário.

Diariamente, todas as flores masculinas do progenitor feminino eram retiradas antes da sua abertura, para evitar uma possível autofecundação. Iniciou-se a polinização 41 dias após o plantio da linhagem feminina, utilizando cinco diferentes quantidades de pólen para polinizar uma única flor feminina: um quarto da quantidade de pólen de uma flor; metade da quantidade de pólen de uma flor; a quantidade de pólen de uma flor; a quantidade de pólen de duas flores e, a quantidade de pólen de quatro flores masculinas. Para a obtenção da quantidade média de pólen de uma flor foram coletadas dez flores masculinas do progenitor masculino e com um estilete foram cortadas as suas pétalas e os estames foram raspados levemente para a retirada apenas do pólen. O pólen coletado foi depositado em um papel alumínio e pesado para a obtenção do peso total. A partir do valor obtido foi calculado o peso médio de pólen de uma flor que correspondeu a $47 \mathrm{mg}$. As polinizações foram realizadas no período da manhã. O pólen, após pesado, foi colocado em um recipiente cilíndrico, utilizando um medidor de sal para o preparo de soro caseiro, para facilitar a polinização. A polinização foi realizada com o cuidado de que todo o pólen ficasse aderido ao estigma. Somente duas flores por planta foram polinizadas. Todas as flores polinizadas foram etiquetadas. A colheita dos frutos foi realizada após 50 a 60 dias da polinização e permaneceram em repouso por mais 15 dias em local arejado e seco, antes da extração de sementes.

As sementes foram extraídas e lavadas em água corrente, com a utilização de cal virgem, para remoção da fina camada de mucilagem que as recobria. Após a extração, as sementes foram postas em uma sala de pré-secagem por 48 horas a uma temperatura de $32^{\circ} \mathrm{C}$ e, posteriormente, em uma estufa elétrica por 24 horas a uma temperatura de $40^{\circ} \mathrm{C}$.

Foram avaliados os parâmetros: a) peso de frutos (PF): os frutos foram pesados em balança de precisão após 15 dias de repouso; b) estimativa da produtividade de frutos (PRF): estimou-se a produtividade de frutos por hectare, a partir do peso total de frutos obtido na parcela de $9 \mathrm{~m}^{2}$; c) peso de sementes total por fruto (PSTF): as sementes de cada fruto foram pesadas em balança de precisão, antes de serem passadas pelo soprador; d) peso de sementes por fruto (PSF): as sementes de cada fruto foram pesadas em balança de precisão, depois de serem passadas por um soprador pneumático (eliminação de sementes chochas, mal formadas, leves, etc.); e) estimativa da produção de sementes por área (PRS): foi calculada a partir do valor obtido na parcela de $\left.9 \mathrm{~m}^{2} ; \mathbf{f}\right)$ número de sementes por fruto (NSF): as sementes de cada fruto foram contadas manualmente; g) pegamento (PEG): obtido pela porcentagem de flores que se transformaram em frutos após a polinização, em 36 flores totais polinizadas na parcela; h) peso de $\mathbf{1 0 0}$ sementes (P100): quatro repetições de 100 sementes, por tratamento, foram tomadas aleatoriamente e pesadas em balança de precisão; i) teste de germinação (GER) e vigor (1 ${ }^{\text {a }}$ contagem): foram utilizadas quatro repetições de 50 sementes por tratamento, em um delineamento inteiramente casualizado. As sementes foram semeadas em rolo de papel (RP), contendo três folhas de papel filtro, previamente umedecidas com água destilada, e incubadas na temperatura alternada de $20^{\circ} \mathrm{C}(16 \mathrm{~h})$ e $30^{\circ} \mathrm{C}(8 \mathrm{~h})$, de acordo com as Regras para Análise de Sementes (Brasil, 1992). A primeira contagem, aos 4 dias após a instalação do teste foi considerada como o vigor das sementes e a contagem final, após 8 dias, foi considerada como a germinação das sementes; j) emergência das plântulas em substrato (ES): foram utilizadas quatro repetições de 50 sementes por tratamento, em um delineamento inteiramente casualizado. As sementes foram colocadas em caixas de poliestireno expandido (isopor) contendo 200 células em substrato tipo Plantmax Hortaliças (Eucatex). As bandejas permaneceram durante todo o período em casa de vegetação e o substrato foi mantido suficientemente úmido a fim de dar à semente a quantidade de água necessária para a germinação. Efetuouse a contagem das plântulas aos 10 dias após a semeadura.

Os dados obtidos neste estudo fo- 
ram submetidos à análise de variância, comparando as médias dos tratamentos através do teste Tukey a 5\% de probabilidade para a análise dos parâmetros de qualidade de sementes (P100, Primeira contagem, Germinação e Emergência em substrato). Os outros dados de produção de frutos e sementes foram avaliados pela análise de regressão.

\section{RESULTADOS E DISCUSSÃO}

O cruzamento entre $C$. maxima e $C$. moschata resultou em pegamento máximo de frutos de $50 \%$ quando se utilizou a quantidade de pólen de quatro flores e o mínimo de $22 \%$ quando se utilizou um quarto da quantidade de pólen de uma flor. Observou-se uma relação direta do pegamento dos frutos com a quantidade de pólen utilizada na polinização das flores onde, quanto maior a quantidade de pólen utilizada na polinização de flores de C. maxima, maior foi o pegamento de frutos (Figura 1A). Segundo Whitaker \& Davis (1962), no cruzamento de $C$. maxima x C. moschata cerca de 30 a $40 \%$ de polinizações originaram frutos. Valores aproximados também foram citados por Takashima (1954) que obteve $42 \%$ de pegamento ao polinizar 750 flores de C. maxima. Yamane (1952), ao polinizar 58 flores, conseguiu somente oito frutos, ou seja, aproximadamente $14 \%$ de pegamento. As causas destes diferentes valores de pegamento são discutíveis, podendo-se levantar a hipótese da utilização de linhagens com diferentes graus de compatibilidades ou o cultivo em diferentes condições edafoclimáticas. Condições adversas de desenvolvimento da flor, polinização ou fertilização usualmente resultam em um pequeno ou anormal desenvolvimento do fruto (Zitter et al., 1996).

Não foi observada diferença significativa no peso dos frutos quando da polinização com diferentes quantidades de pólen, porém existiu uma tendência dos frutos obtidos da polinização com quatro flores (188 mg de pólen) serem maiores e, consequentemente, mais pesados (Figura 1B). O maior tamanho dos frutos pode ser explicado pela maior quantidade de sementes no fruto e também pela presença de maior quantidade de auxina no grão de pólen. A germi- nação do grão de pólen é muitas vezes o estimulante para o desenvolvimento do ovário quando há uma polinização eficiente. Os grãos de pólen possuem alta taxa de auxina que tem como função garantir a manutenção e o crescimento do ovário da flor. Uma polinização com grande quantidade de pólen geralmente resulta em uma explosão no crescimento do ovário e aumento do pegamento. Desde a polinização, a auxina age na formação do ovário (Kessel, 1976). Sem a fecundação, o ovário se desprende e cai. Embora o pólen tenha poucas horas para alcançar os óvulos, se a taxa de elongação do fruto exceder a taxa de crescimento do tubo polínico, os óvulos nunca serão fertilizados devido à maior distância dos óvulos nos frutos longos (Robinson \& Decker-Walters, 1996). Assim, a auxina presente, até mesmo quando foi utilizada a quantidade de pólen de quatro flores, pode não ter ocasionado este crescimento exagerado do fruto, antes da fecundação dos óvulos, pois não se observou redução no número de sementes por fruto ao se aumentar a quantidade de pólen (Figura 1C).

As plantas polinizadas com a quantidade de pólen de duas (94 mg) a quatro (188 mg) flores apresentaram maior percentagem de pegamento de frutos (Figura 1A). Soma-se a isto uma percentagem maior de plantas com dois frutos nestes tratamentos, contribuindo para a obtenção de valores crescentes de produção de frutos com o aumento da quantidade de pólen utilizada (Figura 1D).

A maior produção de frutos ocorreu quando a polinização foi realizada com $188 \mathrm{mg}$ de pólen, alcançando aproximadamente $30 \mathrm{t} /$ ha (Figura 1D). Existe uma tendência dos frutos mais pesados apresentarem maior número de sementes por fruto (Figura 1C), maior peso de sementes por área (Figura $1 \mathrm{~F}$ ) e maior produção de sementes/fruto (Figura 1E). Hayase (1953), Stephenson et al. (1988) e Zitter et al. (1996) observaram o mesmo, onde o tamanho do fruto e conseqüentemente o seu peso aumentam com o número de sementes no fruto. Lima et al. (1999) trabalhando com duas quantidades de pólen (50\% de uma antera e uma antera inteira) para polinizar abobrinha cv. Caserta também verifica- ram que o uso da metade da quantidade de pólen de uma antera propiciou menor peso de sementes (por fruto, planta e área), e originou frutos com menor produção de sementes e consequentemente de menor peso; o peso médio de fruto não foi influenciado pela quantidade de pólen. Cardoso (2003), utilizando três quantidades de pólen (meia, uma e duas flores) na polinização de abobrinha (Cucurbita pepo), não encontrou diferença significativa no pegamento, peso médio de frutos e número e peso de sementes por fruto.

O maior número de sementes encontrado por fruto foi de aproximadamente 117 quando utilizada a quantidade de pólen de quatro flores. Quanto mais eficiente for o processo de polinização, ou seja, quanto maior for o número de grãos de pólen viáveis e compatíveis no estigma, maior será a fecundação dos óvulos e consequentemente a quantidade de sementes formadas. A quantidade de sementes obtida, usandose a quantidade de pólen de uma flor, foi um pouco menor, aproximadamente 87 sementes por fruto (Figura 1C). O baixo pegamento de frutos $(22 \%)$ (Figura 1A) obtido quando houve a polinização com 1/4 de pólen de uma flor pode estar diretamente relacionado com a quantidade de pólen utilizada e o número de sementes formadas no fruto. Lee \& Bazzaz (1982) têm sugerido que, através do abortamento de frutos com poucas sementes, a planta pode eliminar todos os frutos na qual teve pouca competição pelo acesso aos óvulos e, um aborto seletivo de frutos com poucas sementes pode ser visto como um meio de aumentar a qualidade das sementes produzidas. Finalmente, verificou-se influência direta da quantidade de pólen utilizada na polinização e produção de sementes. Quanto maior a quantidade de pólen utilizada, maior a quantidade de sementes produzida (Figura 1F). A maior produção de sementes alcançada foi de $520 \mathrm{~kg} /$ ha utilizando-se $188 \mathrm{mg}$ de pólen, e a menor foi de $160 \mathrm{~kg} / \mathrm{ha}$ utilizando-se $11 \mathrm{mg}$ de pólen.

Não foi observada diferença significativa entre as diversas quantidades de pólen utilizadas na polinização para a maioria dos parâmetros de qualidade das sementes (P100, vigor, emergência 
em substrato) (dados não apresentados), corroborando os dados obtidos por Cardoso (2003) em abobrinha (C. pepo). A geminação das sementes tendeu a aumentar com o aumento da quantidade de pólen depositado no estigma (Jennings \& Tophan, 1971). Lima (2000), trabalhando com abobrinha (C. pepo), verificou aumento na germinação e vigor quando utilizou a maior quantidade de pólen (100\% da antera). No presente estudo, a germinação das sementes foi menor $(75 \%)$ quando foi utilizada a menor quantidade de pólen e foi maior (94\%) quando se utilizou a quantidade de pólen de duas flores.
Davis et al. (1987) e Winsor et al. (1987) também trabalhando com abobrinha e Quesada et al. (1996) trabalhando com abobrinha interespecífica (C. pepo x $C$. texana), observaram que sementes produzidas com elevada quantidade de pólen possuíam maior vigor do que as produzidas com baixa quantidade de

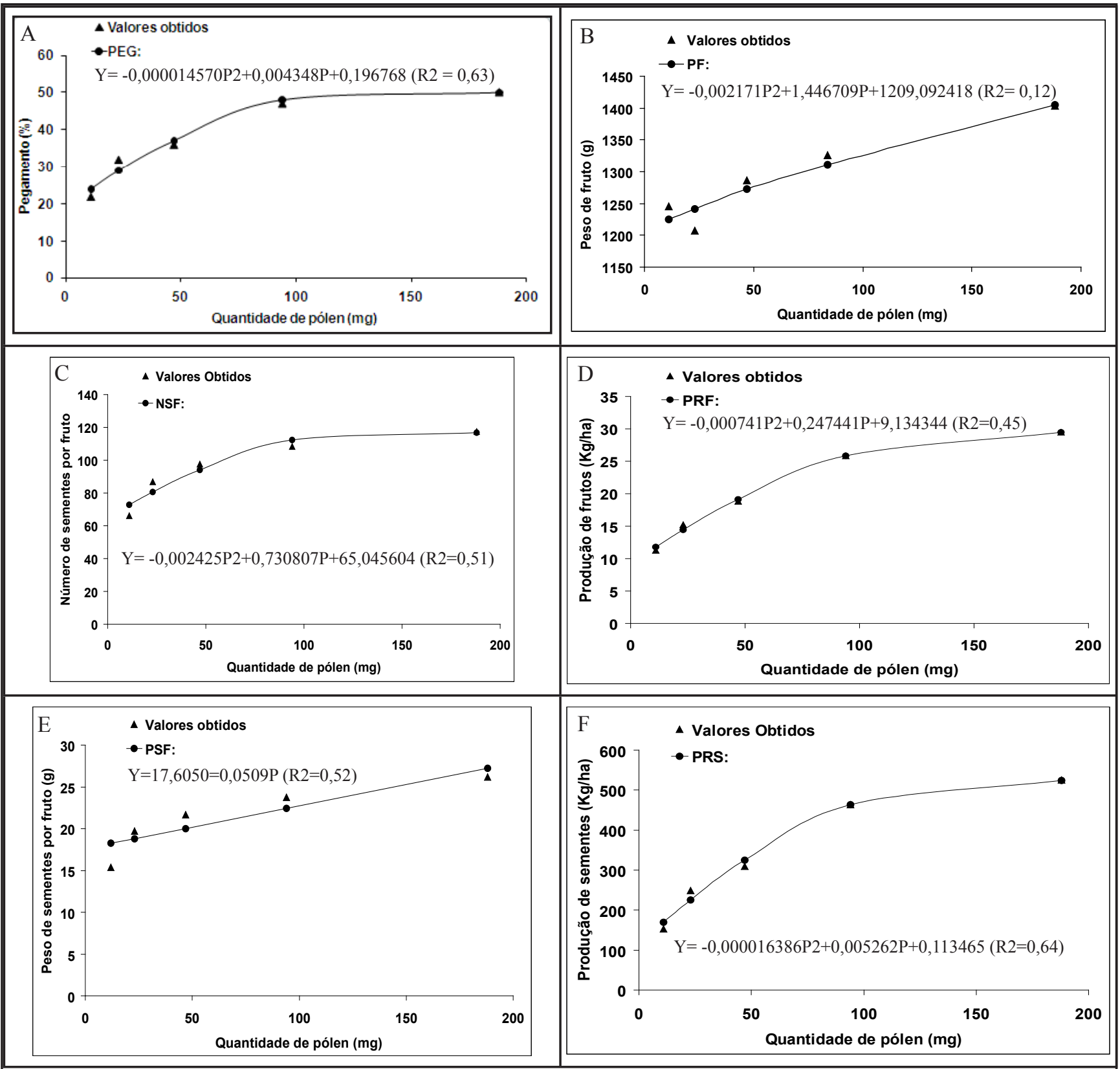

Figura 1. A) Pegamento de frutos de abóbora híbrida procedentes de polinização com diferentes quantidades de pólen (squash fruit setting from pollination using different pollen amounts); B) Peso de frutos de abóbora em função de diferentes quantidades de pólen (squash fruit weight from pollination using different pollen amounts); C) Número de sementes por fruto de abóbora híbrida procedentes da polinização com diferentes quantidades de pólen (squash seed number per fruit from pollination using different pollen amounts); D) Produção de frutos de abóbora híbrida procedentes da polinização com diferentes quantidades de pólen (squash fruit yield from pollination using different pollen amounts); E) Peso de sementes por fruto de abóbora híbrida procedentes da polinização utilizando diferentes quantidades de pólen (weight of seeds per hybrid squash fruit from pollination using different pollen amounts); F) Produção de sementes de abóbora híbrida procedentes da polinização com diferentes quantidades de pólen (squash seed production from pollination using different pollen amounts). Brasília, Embrapa Hortaliças, 2003. 
pólen. Embora não significativo, os dados numéricos de vigor (emergência em solo) no presente estudo mostram a superioridade da emergência em solo nos tratamentos onde utilizaram-se maiores quantidades de pólen (dados não apresentados). A explicação para tal acontecimento deve-se a uma relação de quanto maior a quantidade de pólen no estigma, maior é a possibilidade de se ter grãos de pólen mais vigorosos. Estes, por sua vez, são mais competitivos, aumentando a capacidade de fertilizar os óvulos e gerar sementes mais vigorosas.

Finalmente, a quantidade de pólen pode interferir na produção e na qualidade de sementes híbridas de abóbora onde a utilização de pólen de quatro flores de C. moschata na polinização de uma flor de $C$. maxima ocasionou uma maior produção de sementes.

\section{REFERÊNCIAS}

BRASIL. MINISTÉRIO DA AGRICULTURA E REFORMA AGRÁRIA. 1992. Regras para análise de sementes. Brasília: SNDA: DNVD: CLAV, 220p.

CARDOSO AII. 2003. Produção e qualidade de sementes de abobrinha 'Piramoita' em resposta à quantidade de pólen. Bragantia 62: 47-52.

DAVIS LE; STEPHENSON AG; WINSOR
JA. 1987. Pollen competition improves performance and reproductive output of the common zucchini squash under field conditions. Journal of the American Society for Horticultural Science 112: 712-716.

EMBRAPA. 2003, 30 de novembro. Abóbora. Disponível em http://www.cnph.embrapa.br/ noticias/hortinforme_ed_13/pric_not $1 . h$ tm

FNPCONSULTORIA\&AGROINFORMATIVOS (São Paulo, SP). 2003. Agrianual 2004: anuário da agricultura brasileira. São Paulo, 496p.

FREITAS BM. 1997. Changes with time in the germinability of cashew (Anacardium occidentale) pollen grains found on different body areas of its pollinator bees. Review of Brasilian Biology 57: 289-294.

HAYASE H. 1953. Cucurbita-crosses. IV. The development of squash fruit as affected by placement of pollen on stigma. Hokkaido National Agricultural Experiment Station, Research B 64: 22-25 [In Japanese, English summary].

QUESADA M; WINSOR JA; STEPHENSON AG. 1996. Effects of pollen selection on progeny vigor in Cucurbita pepo x C. texana hybrid. Theoretical and Applied Genetics 92: 885-890.

KESSEL RG; SHIH CY. 1976. Scanning electron microscopy in biology. New York: SpringerVerlag, 345p.

JENNINGS DL; TOPHAM PB. 1971. Some consequences of raspberry pollen dilution for its germination and or fruit development. New Phytology 70: 371-380.

LEE TD; BAZZAZ FA. 1982. Regulation of fruit maturation pattern in an annual legume, Cassia fasciculata. Ecology 63: 1374-1388.
LIMA MS; CARDOSO AII; VERDIAL MF. 1999. Efeito da competição entre plantas e pólen na produtividade de sementes de abobrinha cv. Caserta. Horticultura Brasileira 17: 163.

LIMA MS. 2000. Espaçamento entre plantas e quantidade de pólen na produção e qualidade de sementes de abobrinha (Cucurbita pepo). Botucatu: UNESP-FCA. 75p (Tese mestrado).

ROBINSON R. W; DECKER-WALTERS DS. 1996. Cucurbits. CAB International: New York, $226 \mathrm{p}$.

STEPHENSON AG; DEVLIN B; HORTON JB. 1988. The effects of seed number and prior fruit dominance on the pattern of fruit production in Cucurbita pepo (zucchini squash). Annals of Botany 62: 653-661.

TAKASHIMA S. 1954. The growth rate of pollen tubes in interespecific hybrid of Cucurbita. II: The growth rate of pollen tubes in intraspecific mating. Japanese Journal of Genetics 29: 36-39 (In Japanese, English summary).

WINSOR JA; DAVIS LE; STEPHENSON AG. 1987. The relationships between pollen load and fruit maturation and its effect on offspring vigor in Cucurbita pepo. American Naturalist 112: 712-716.

WHITAKER TW; DAVIS GN. 1962. Cucurbits: botany, cultivation and utilization. Leonard Hill: New York, 250p.

YAMANE Y. 1952. Studies on species hybrids in genus Cucurbita. I: C. maxima and C. moschata and its reciprocal cross. Republic Kihara Institute for Biological Research 5: 94-99.

ZITTER TA; HOPKINS DL; THOMAS CE. (eds). 1996. Compendium of cucurbit diseases St. Paul: APS Press, $87 \mathrm{p}$. 